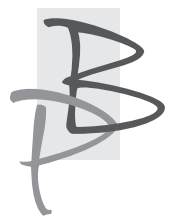

Irena Fedorowicz*

https://orcid.org/0000-0002-4294-0653

Kinga Geben**

https://orcid.org/0000-0001-6107-019

Uniwersytet Wileński, Litwa

\title{
Konotacje Wilna w polskiej wersji książki Algisa Kalėdy W poszukiwaniu poetyckiej tożsamości Wilna (2016)
}

Streszczenie: Autorki artykułu, w oparciu o metodologię literaturoznawczą i językoznawczą, analizują sylwetkę twórczą oraz dorobek profesora Algisa Kalèdy (1952-2017), znanego litewskiego badacza literatury, poety, krytyka literackiego i tłumacza. Główny obiekt analizy obu autorek to zbiór esejów Kaledy pt. W poszukiwaniu poetyckiej tożsamości Wilna (2016), a celem analizy jest ukazanie wielokulturowych kontekstów w recepcji tego wyjątkowego miasta.

Słowa-klucze: Algis Kaléda, Wilno, językowy obraz miasta, konotacje.

* Irena Fedorowicz - dr nauk hum., pracownik naukowo-dydaktyczny Instytutu Języków i Kultury Regionu Bałtyckiego Uniwersytetu Wileńskiego. Opublikowała ponad 40 artykułów w pracach zbiorowych, wydała m.in. monografię $W$ stużbie ziemi ojczystej. Czesław Jankowski w życiu kulturalnym Wilna lat 1905-1929 (Kraków 2005). (Kontakt: Irena.fedorovic@flf.vu.lt)

** Kinga Geben - dr nauk hum., pracownik naukowo-dydaktyczny Instytutu Językoznawstwa Stosowanego Uniwersytetu Wileńskiego. Opublikowała m.in. monografię Świadomość i kompetencja językowa a warstwy leksykalne w idiolektach młodzieży polskiego pochodzenia na Wileńszczyźnie (Warszawa 2003), a także kilkadziesiąt artykułów. (Kontakt: Kinga.geben@flf.vu.lt) 


\section{Connotations of Vilnius in the Polish version of Algis Kalèda's book In the Search of the Poetic Identity of Vilnius (2016)}

Summary: The authors of the article, on the ground of literary and linguistic methodology, analyze the creative profile and achievements of Professor Algis Kalèda (1952-2017), a well-known Lithuanian literature researcher, poet, literary critic and translator. The main object of the analysis is a collection of Kaleda's essays In the Search of the Poetic Identity of Vilnius (2016), and the purpose of the analysis is to show multicultural contexts in the reception of this unique city.

Key words: Algis Kalèda, Vilnius, linguistic image of the city, connotations

\section{Wstęp}

Wilno - niegdyś stolica Wielkiego Księstwa Litewskiego, a od ponad 25 lat - niepodległej Litwy, zajmuje wyjątkowe miejsce w kulturze litewskiej i polskiej. Jego obraz jest utrwalony w wielu dziełach literackich, malarskich, muzycznych, funkcjonuje w wyobraźni i pamięci zbiorowej, jak też indywidualnej. To zagadnienie z perspektywy odbiorcy XX wieku w odległym 1990 roku trafnie ujęła publicystka warszawska Elżbieta Sawicka:

Każdy ma swoje Wilno. Jedni zapamiętane sprzed lat - przedwojenne, wojenne czy tuż powojenne, ale realne. Prawdziwe miasto z prawdziwymi domami, z pobożnym tłumem klęczącym pod Ostrą Bramą, z kaziukowymi palmami na placu Łukiskim, ze zniczami na Rossie w dzień Wszystkich Świętych. Z drewnianymi domkami Kazimierza, z kałużami na ulicy Niemieckiej.

Inni mają Wilno mityczne. Imaginacyjne. Miasto z Dziadów Mickiewicza, z książek Miłosza i Konwickiego. Zbudowane w wyobraźni. Przemierzone w myśli ze starym planem w ręku, mozolnie zrekonstruowane krok po kroku, ulica po ulicy. Zobaczone oczyma Kirkora, prof. Kłosa, wysnute z Albumu Wileńskiego Wilczyńskiego - w ogólnych zarysach, bez detali i bez pewności, czy prawdziwe. Takie Wilno jak na obrazie Mikalojusa Konstantinasa Čiurlionisa Jeździec, na którym 
widać jakiś mityczny senny gród na wzgórzach, z wieżami kościołów i pałacami. Nad miastem - skaczący w przestrzeń i jeździec z mieczem w dłoni. Vitis. A miasto, choć niby nie jest, to przecież jest Wilnem ${ }^{1}$.

Ta wypowiedź jest punktem wyjścia dla naszych rozważań na temat obrazu dawnego grodu Giedyminowego, występującego w pracach profesora Algisa Kaledy, wilnianina z wyboru, Litwina rozmiłowanego w kulturze polskiej, zasługującego na miano „ambasadora dwojga narodów” w niepodległej Litwie.

\section{Algis Kalėda (1952-2017). Sylwetka twórcy}

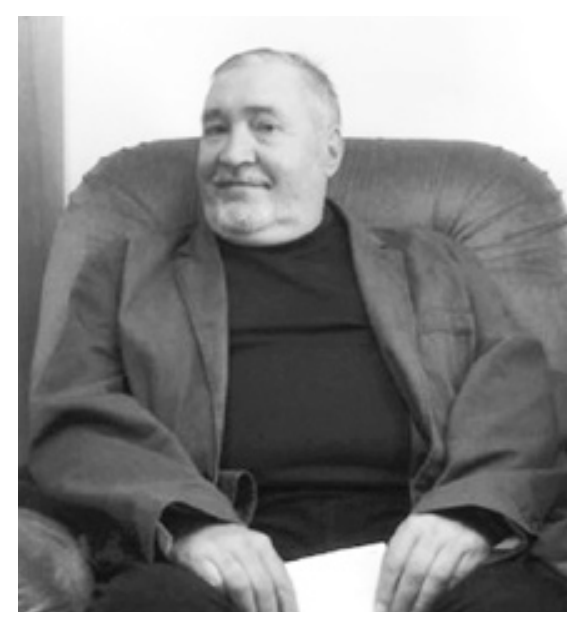

Ostatnie zdjęcie prof. Algisa Kalèdy w „fotelu Miłosza” w Centrum Polonistycznym Uniwersytetu Wileńskiego (fot. studentka Joanna Rozmysłowicz)

Algis Kalėda, jedyny na Litwie profesor równocześnie lituanistyki i polonistyki, urodził się 2 października 1952 roku we wsi Mašnyčiai w rejonie orańskim (lit. Varẻnos rajonas) w pobliżu Druskienik, dzieciństwo i lata szkolne spędził w tym uroczym mieście uzdrowiskowym. W 1970 roku rozpoczął studia lituanistyczne na Uniwersytecie Wileńskim, po dwóch latach w ramach wymiany został skierowany na Uniwersytet Jagielloński w Krakowie, gdzie podjął studia na kierunku filologia polska. Najbardziej pociągały

\footnotetext{
1 E. Sawicka, Moje Wilno, „Odra. Miesięcznik Społeczno-Kulturalny” 1990, nr 6, s. 21.
} 
go historia literatury polskiej oraz teoria literatury. Po ukończeniu studiów w 1977 roku został zatrudniony w Instytucie Literatury Akademii Nauk Litwy (obecnie Instytut Literatury Litewskiej i Folkloru), ta placówka była jego podstawowym miejscem pracy. W latach 1982-1984 wykładał też na polonistyce w Wileńskim Instytucie Pedagogicznym (obecnie Litewski Uniwersytet Edukologiczny). Od 1984 roku, po obronie doktoratu, podjął dodatkową pracę na Uniwersytecie Wileńskim, gdzie prowadził zajęcia lituanistyczne. Od 1999 roku był profesorem tej uczelni. W latach 1991-1993 pracował jako lektor języka litewskiego na Uniwersytecie Warszawskim. Właśnie pobyt na tej uczelni, kontakty z warszawskimi bałtystami przekonały go o potrzebie uruchomienia na Uniwersytecie Wileńskim studiów polonistycznych między innymi dla osób, które mogłyby się uczyć języka polskiego od zera. Chodziło również o odrodzenie chlubnych tradycji polonistyki wileńskiej z okresu dwudziestolecia międzywojennego. Dzięki Profesorowi w 1993 roku powstała Katedra Filologii Polskiej (przemianowana w 2007 roku na Centrum Polonistyczne), którą kierował w latach 1993-2007 i 2012-2016.

Tego sukcesu gratulowało mu wielu znanych ludzi, wśród nich absolwenci Uniwersytetu Stefana Batorego prof. Irena Sławińska, prof. Czesław Zgorzelski oraz Czesław Miłosz². Pomyślny start nowej wileńskiej polonistyki na Uniwersytecie Wileńskim był niewątpliwie zasługą prof. Algisa Kaledy, jego „umiejętności i pozycji naukowej”’3. Kierownik Katedry Filologii Polskiej wspólnie z prof. drem hab. Tadeuszem Bujnickim, historykiem literatury z Uniwersytetu Jagiellońskiego i prof. dr hab. Elżbietą Janus, językoznawczynią z Instytutu Badań Literackich PAN w Warszawie, opracował program studiów polonistycznych na Uniwersytecie Wileńskim. W programie tym została uwzględniona potrzeba prowadzenia badań komparatystycznych nad „stykiem” różnych literatur i kultur, fenomenem dwuszczeblowej tożsamości, nad wielokulturowością Wilna. Właśnie ten kierunek badań był charakterystyczny dla samego Profesora i jego uczniów.

2 J. Rozmysłowicz, Pierwsze spotkanie z Miłoszem byto dziwne. Wywiad z prof. A. Kalėdą: zw.lt/radar-wilenski/kaleda-pierwsze-spotkanie-z-miloszem-bylo-dziwne [dostęp: 17.05. 2016].

3 T. Bujnicki, Uwagi o badaniach nad literatura (na dziesięciolecie Katedry Filologii Polskiej), [w:] tegoż, Na pograniczach, kresach i poza granicami. Studia, oprac. tekstu i red. tomu M. Siedlecki i Ł. Zabielski, Białystok 2014, s. 384. 
W ciągu ponad 20 lat pracy na Uniwersytecie Wileńskim prof. A. Kalėda wypromował liczne grono absolwentów polonistyki, a także lituanistów, którzy zajmowali się badaniem związków literackich polsko-litewskich oraz recepcji literatury polskiej na Litwie i litewskiej w Polsce. Był też przewodniczącym i jurorem Olimpiady Literatury i Języka Polskiego na Litwie. W 2014 roku został laureatem Nagrody „Polonicum” Uniwersytetu Warszawskiego „za wybitne osiągnięcia w krzewieniu języka polskiego i kultury polskiej za granicą"4.

W 2015 roku udał się na wcześniejszą emeryturę. Do końca życia był związany z rodzimą placówką, Instytutem Literatury Litewskiej i Folkloru, gdzie przez kilka lat pełnił funkcję dyrektora. Zmarł nagle w 2017 roku w Wilnie, z którym był związany przez 40 lat. W pamięci przyjaciół naukowców z Polski pozostanie jako ,serdeczny i pomocny we wszystkim Człowiek, wielki Humanista", który uważał, że właśnie na humanistach spoczywa obowiązek pojednania między narodami i sam na tym polu dokonał niewyobrażalnie wiele" (prof. dr hab. Zbigniew Kopeć, dyrektor Instytutu Filologii Polskiej Uniwersytetu im. Adama Mickiewicza w Poznaniu) $)^{5}$. Był on badaczem, który ,jak nikt inny potrafił łączyć przedstawicieli różnych środowisk i narodowości, nadać głęboki sens badaniom nad literaturą powstającą na styku kultury polskiej i litewskiej” (prof. dr hab. Tomasz Chachulski, Instytut Badań Literackich PAN) ${ }^{6}$.

Algis Kalèda jest autorem wielu prac naukowych z dziedziny teorii literatury litewskiej, historii literatury polskiej i litewskiej, przekładów XX-wiecznej literatury polskiej na język litewski (tłumaczył między innymi Dolinę Issy, Szukanie ojczyzny oraz poezje Czesława Miłosza, utwory Wisławy Szymborskiej, Sławomira Mrożka, Stanisława Lema, Witolda Gombrowicza, Brunona Schulza). W wywiadzie udzielonym w 1995 roku powiedział on:

Wybieram do tłumaczenia utwory, które według mnie są wartościowe, które mogą pokazać człowiekowi drogę do Światła. Staram się, żeby czytelnik litewski jaśniej zobaczył to, co czym naprawdę szczyci się literatura polska - szla-

4 I. Fedorowicz, „Filologia kłopotliwej mniejszości”. Wczoraj i dzisiaj polonistyki na Uniwersytecie Wileńskim, „Rocznik Stowarzyszenia Naukowców Polaków Litwy” 2016, t. XVI, s. 110.

5 Tekst kondolencji odczytanych podczas pogrzebu w dn. 14.05. 2017. Archiwum Centrum Polonistycznego Uniwersytetu Wileńskiego.

6 Tamże. 
Irena Fedorowicz, Kinga Geben, Konotacje Wilna w polskiej wersji książki Algisa Kalèdy...

chetność, miłość, szacunek do człowieka, niechęć do prymitywnych schematów, a przede wszystkim - umiłowanie wolności?

W języku polskim ukazały się między innymi następujące książki (monografie i zbiory szkiców) Algisa Kalėdy: Powojenna literatura litewska. Droga strat i nadziei (Vilnius 1998), Dzieje literatury litewskiej 1918-2000 (Warszawa 2000), Od M do M. Szkice o literaturze polskiej i litewskiej (Warszawa 2005). Profesor był też współautorem publikacji Słownik litewsko-polski (Vilnius 1991), Rozmówki litewsko-polskie (Warszawa 2008, wspólnie z żoną Barbarą Kalèdą), Litwo, matko nasza miła... Antologia literatury polskiej o Litwie (Vilnius 1996, wspólnie z prof. Reginą Koženiauskienė i Barbarą Kalėdą). W jego dorobku jest ponad 120 artykułów i recenzji w językach litewskim, polskim i angielskim. Wyjątkowe miejsce w pracach profesora zajmowało badanie literackiego obrazu Wilna, temu tematowi poświęcił on kilka publikacji, między innymi w języku polskim ${ }^{8}$. Ostatnią jego pracą poświęconą tej problematyce jest skrypt akademicki wydany w 2016 roku w trzech językach (polskim, litewskim i angielskim) pt. W poszukiwaniu poetyckiej tożsamości Wilna, skierowany do studentów kierunków humanistycznych i programu wymiany międzynarodowej ERASMUS ${ }^{9}$. Publikacja ta - zgodnie z założeniem Autora jest poetycką historią stolicy Litwy, ujętą w formie eseju literackiego, która ma pomóc odbiorcy w doświadczeniu uroku poetyckiego Wilna i być zachętą do głębszego poznania jego wieloetnicznej kultury. Książka składa się z dwóch esejów - Oblicza miasta oraz Topika literacka we współczesnej poezji polskiej na Litwie. Dodatkiem do niej są dwie odrębne (polska i litewska) antologie, zawierające wybrane teksty poetyckie poświęcone tematyce wileńskiej autorstwa najbardziej reprezentatywnych twórców łacińsko-, polsko- i litewskoję-

7 W. Zajączkowska, Literackie zwiazki nierozłaczne. Rozmowa z doc. dr. Algisem Kalèda, kierownikiem Katedry Filologii Polskiej Uniwersytetu Wileńskiego, „Słowo Wileńskie" 1996, nr 20 (17-23 maja), s. 9.

8 Wybór artykułów A. Kalèdy na ten temat: Pomiędzy dwiema Ojczyznami, „Kwartalnik Polonicum" 2015, nr 18, s. 44-49; Mityczne miasto (Literackie obrazy Wilna), [w:] tegoż, Od M do M. Szkice o literaturze polskiej i litewskiej, Warszawa 2005, s. 61-76; Szukanie Wilna, czyli jak być Europejczykiem, [w:] W ogrodzie świata. Profesorowi Aleksandrowi Fiutowi na siedemdziesiąte urodziny, pod red. Ł. Tischnera i J. Wróbla, Kraków 2015, s. 221-230.

9 A. Kalèda, Ieškant poetinès Vilniaus tapatybès / W poszukiwaniu poetyckiej tożsamości Wilna/ In search of poetical identity of Vilnius, Wilno 2016, s. 16-24, 49-65. 
zycznych, ułożone w kolejności chronologicznej. Ze zrozumiałych względów będzie nas interesowała wyłącznie polska wersja dwóch esejów oraz komentarze do antologii tekstów polskich, których jest więcej niż litewskich ${ }^{10}$.

\section{Metoda badawcza. Analiza konotacji miasta w pracy W poszukiwaniu poetyckiej tożsamości Wilna (2016)}

Zagadnienie językowego obrazu świata (JOS), od którego chcemy zacząć rozważania nad tekstem Kalėdy, jest opisane w pracach autorstwa między innymi Jerzego Bartmińskiego ${ }^{11}$, Stanisławy Niebrzegowskiej-Bartmińskiej ${ }^{12}$, Renaty Grzegorczykowej ${ }^{13}$ oraz Anny Kozłowskiej ${ }^{14}$. Odwołujemy się do szerokiej definicji JOŚ sformułowanej przez Jerzego Bartmińskiego:

Językowy obraz świata jest zawartą w języku interpretacją rzeczywistości, dającą się ująć w postaci zespołu sądów o świecie, o ludziach, rzeczach, zdarzeniach. Jest interpretacją, a nie odbiciem, jest subiektywnym portretem, a nie fotografią przedmiotów realnych. Interpretacja ta jest rezultatem subiektywnej percepcji i konceptualizacji rzeczywistości przez mówiących danym językiem, ma więc charakter wyraźnie podmiotowy, antropocentryczny, ale zarazem jest intersubiektywna w tym sensie, że podlega uspołecznieniu i staje się czymś, co łączy ludzi w danym kręgu społecznym, czyni z nich wspólnotę myśli, uczuć i wartości;

$10 \mathrm{~W}$ antologii polskiej znajduje się 17 utworów 11 różnych autorów, tworzących w XVI-XXI w. Litewska poezja jest reprezentowana przez 11 utworów autorstwa 10 poetów litewskich z XX-XXI w.

11 J. Bartmiński, Perspektywa semazjologiczna i onomazjologiczna badaniach językowego obrazu świata, „Poradnik Językowy” 2015, z. 1, s. 14-29.

12 J. Bartmiński, S. Niebrzegowska, Profile a podmiotowa interpretacja świata, [w:] Profilowanie w języku $i$ w tekście, pod red. J. Bartmińskiego, R. Tokarskiego, Lublin 1998, s. 211-224.

13 R. Grzegorczykowa, Pojęcie językowego obrazu świata, [w:] Językowy obraz świata, pod red. J. Bartmińskiego, Lublin 1999, s. 39-46.

14 A. Kozłowska, Problemy z idiolektem, [w:] Język pisarzy jako problem lingwistyki, pod red. T. Korpysza, A. Kozłowskiej, t. II, Warszawa 2009, s. 111-131; A. Kadyjewska, Problematyka obrazu świata w badaniach języka pisarza (na przyktadzie pism Cypriana Norwida), [w:] Semantyka tekstu artystycznego, pod red. A. Pajdzińskiej, R. Tokarskiego, Lublin 2001, s. 321-332. 
czymś, co wtórnie wpływa (z jaką siłą - to już jest przedmiotem sporu) na postrzeganie i rozumienie sytuacji społecznej przez członków wspólnoty ${ }^{15}$.

Według Renaty Grzegorczykowej składnikami językowego obrazu świata, które odsłaniają sposób, w jaki ujmowane są zjawiska świata przez mówiących, są własności gramatyczne języka, zjawiska leksykalne, własności słowotwórcze leksemów, etymologia, konotacje semantyczne oraz teksty poetyckie. Zjawisko konotacji definiujemy zgodnie z ujęciem badaczki jako „kojarzenie przez mówiących pewnych cech i przekonań z nazywanymi zjawiskami. Te wyobrażenia i przekonania są znakomitym świadectwem językowego ujmowania przedmiotu" 16 .

Językowy obraz Wilna w pracy Algisa Kaledy W poszukiwaniu poetyckiej tożsamości Wilna jest światem stwarzanym przez idiolekt pisarza, kreowanym przez przytaczanie metafor oraz szczególnych słów-kluczy i mitów. Konotacje miasta wyłaniają się z całokształtu wizji, którą ujmujemy w postaci profili. Stanisława Niebrzegowska-Bartmińska stwierdza:

(K)oncepcja profilowania [...] potwierdza i uwydatnia role podmiotu w kreowaniu JOŚ, który nie tylko postrzega rzeczywistość, ale ją aktywnie na różny sposób, konceptualizuje. Profil, będąc wyspecyfikowanym wariantem wyobrażenia bazowego, jest zawsze rezultatem czyjegoś widzenia świata - widzenia w sensie postrzegania z określonego punktu widzenia, widzenia warunkowanego bądź to wielowymiarowością i złożonością samego podmiotu, bądź to wiedzą podmiotu, zajmowanym stanowiskiem, poglądami, intencjami komunikacyjnymi ${ }^{17}$.

Celem analizy jest zatem opisanie „podmiotowej” wizji badanego pojęcia w tekstach wybranego autora. Anna Kadyjewska proponuje opis idiolektalnego obrazu świata, który wyróżnia się jednostkowością wizji ujętej

15 J. Bartmiński, Perspektywa semazjologiczna i onomazjologiczna w badaniach językowego obrazu świata, dz. cyt., s. 15.

16 R. Grzegorczykowa, Pojęcie językowego obrazu świata, [w:] Językowy obraz świata, dz. cyt., s. 47.

17 S. Niebrzegowska-Bartmińska, O profilowaniu językowego obrazu świata, „Poradnik Językowy" 2015, z. 1, s. 42. 
w słowa - teksty autora niosą ze sobą jemu właściwy obraz świata ${ }^{18}$. Badaczka w opisie idiolektalnego obrazu świata w tekstach artystycznych uwzględnia:

1. Wszystkie sposoby wskazywania danego desygnatu, a zatem zaimki oraz nazwy z ich konotacjami [...]; 2. Relacje semantyczne w obrębie nazw; gry językowe związane ze sposobami nazywania desygnatu [...]; 3. Derywaty słowotwórcze i semantyczne nazw [...]; 4. Łączliwość semantyczno-leksykalną nazw (frazeologia, szeroko rozumiane role semantyczne, epitety) [...]; 5. Związane z desygnatem elementy mowy nie wprost: metafory, metonimie, synekdochy, peryfrazy, eksplikacje, porównania, oksymorony, paradoksy [... $]^{19}$.

Ujęcia leksykograficzne wyrazu „miasto” pokazują utrwalone znaczenia w normie oraz uzusie języka litewskiego i polskiego. Znaczenia zawarte w słowniku języka litewskiego ${ }^{20}$ wskazują na wielkość miejscowości, bycie centrum (,centrum administracyjne, handlowe, przemysłowe i kulturowe”) oraz na mieszkańca takiej miejscowości. Z analizy znaczenia zawartego w słownikach języka polskiego ${ }^{21}$ wynika, że miasto jest to ' 1 . duży, gęsto i planowo zabudowany teren, 2. pot. ludność zamieszkująca ten teren, 3. pot. władze administracyjne takiego terenu’. Hiperonim Wilna - „miasto” posiada w języku polskim i litewskim podobne znaczenia oraz zakres użycia, jednakże w myśleniu kulturowo-literackim nazwie miasta „Wilno” (,Vilnius”) przyporządkowano inne konotacje semantyczne, których szczególny splot przedstawiają eseje Profesora.

Analizowana praca jest ostatnią pracą polskojęzyczną, która ukazała się drukiem za życia Algisa Kalėdy. W jednym zbiorze znajduje się wersja książki również w językach litewskim i angielskim. Język polski nie był językiem ojczystym Profesora, lecz językiem nabytym, opanowanym w stopniu doskonałym podczas studiów na Uniwersytecie Jagiellońskim w Krakowie (w latach

18 A. Kadyjewska, Problematyka obrazu świata w badaniach języka pisarza (na przyktadzie pism Cypriana Norwida), dz.cyt., s. 328-329.

19 Tamże, s. 324-326.

20 Dabartinès lietuvių kalbos žodynas, pod red. S. Keinysa, Vilnius 2012, wersja elektroniczna: http://lkiis.lki.lt/, hasło miestas [dostęp 12.12.2017].

21 Por. SL, t. II, s. 78, wersja elektroniczna: http://kpbc.umk.pl/dlibra/publication?id=8173; SJPD, wersja elektroniczna http://doroszewski.pwn.pl/haslo/miasto\%20I/ [dostęp 12.12.2017]. 
1972-1977). Swoje zainteresowania językiem polskim i polonistyką uznał on za „bardzo naturalne”, „zrodzone z chęci poznania tak wspaniałej i wręcz nierozłącznie z Litwą związanej literatury"22. Profile pojęcia Wilna wynikające $\mathrm{z}$ analizy eseju Algisa Kalėdy ujawniają palimpsestowy obraz świata, gdzie realia polskie i litewskie nakładają się na siebie. Poniżej są zestawione syntagmy wypisane z dwóch analizowanych esejów oraz z komentarzy do tekstów zawartych w antologii ${ }^{23}$, w których Autor stosuje nazwę Wilna oraz hiperonim „miasto"; uwzględniono również rzadziej występujące w tekście peryfrazy, metafory i porównania.

Wilno: Poetycka tożsamość Wilna (s. 16, 24); tradycje poezji o Wilnie (s. 16); przestanki poetyckiego i quasi mitologicznego traktowania obrazu Wilna (s. 17); literatura o Wilnie - polska i litewska (s. 17); z mitem o prapoczątkach Wilna (s. 18); obraz Wilna w poezji polskiej (s. 19); litewskie pieśni ludowe o Wilnie (s. 19); sakralna aura otaczajaca Wilno (s. 19); Historia Litwy i Wilna (s. 20, 24); Wilna i catej Litwy (s. 21); sakralizacja Wilna i jego przeszłości (s. 24); tradycje literackie Wilna (s. 23); poetyckie obrazy Wilna (s. 23); o genezie Wilna (s. 84), o założeniu Wilna (s. 86), przekształceń Wilna i całej Litwy (s. 87); wizje o dawnym Wilnie (s. 92); krajobrazy Wilna (s. 92), wielki palimpsest Wilna (s. 94); znane miejsca Wilna (s. 94); przywiazanie poety do Wilna (s. 94); gdyby nadal żyt w Wilnie (s. 94); wracajacy lub przyjeżdżajacy do Wilna (s. 97); wielowyznaniowe Wilno (s. 97); Wilno jako centrum świata (s. 98); Wilno jest ideatem poetyckim (s. 98).

Miasto: oblicza miasta (s.16); przestrzeń literacka miasta (s. 16); temu miastu, tak drogiemu dla wielu narodów (s. 16); aura emocjonalna miasta (s. 17); także jego [miasta] ezoteryczność (s. 17); wizja poetycka miasta (s. 18); poszukiwań tajemniczych źródeł czarującej sity miasta (s. 18); stołecznemu miastu (s. 21); wspaniała przeszlość, wielokulturowe dziedzictwo miasta (s. 23); obraz miasta w poezji jakby migoce (s. 24); dynamiczne ujęcie dziejów miasta (s. 88); tworzenie jakby aureoli miasta (s. 89); wielowarstwowość i dlugowiecz-

22 W. Zajączkowska, Literackie związi nierozłaczne. Rozmowa z doc. dr. Algisem Kaleda, dz.cyt., s. 9.

23 A. Kalèda, Wstęp. Oblicza miasta, [w:] tegoż, Ieškant poetinès Vilniaus tapatybès, dz.cyt., s. 16-24. Tenże, Komentarze, [w:] tegoż, Ieškant poetinès Vilniaus tapatybès, dz.cyt., s. 84-98. 
ność miasta (s. 90); miasto młodości Czestawa Miłosza (s. 92, 94); pożegnanie z miastem (s. 94); wielojęzyczna aura miasta (s. 97).

Inne: wyjątkowość dziejowa tej ziemi (s. 17), magicznych jej [tej ziemi] promieniach (s. 17); stolica Litwy jest pojmowana jako cudowny zamek, stojacy na wysokiej górze (s. 19); oda do Giedyminowego grodu (s. 21); przyszłość stolicy (s. 21); stołecznego miasta Wielkiego Księstwa Litewskiego (s. 84).

Przymiotnik „wileński” wystąpił w następujących określeniach: palimpsestowość poezji wileńskiej (s. 17); , literatury wileńskie” (s. 17 ); topika wileńska (s. 18, 23); tematyka wileńska (s. 23); właściwości „poezji wileńskiej” (s. 22), areat „poezji wileńskiej” (s. 24); dziewiętnastowieczna topografia wileńska (s. 89); niezwykłość wileńskich nekropolii (s. 90); jedna z najgłośniejszych fabut wileńskich (s. 95).

\subsection{Wilno jest stolicą}

$\mathrm{Z}$ analizy dyskursu wynika, że Autor eseju jednoznacznie widzi Wilno jako stolicę, szczególnie ważne i częste jest u niego odwołanie się do „prapoczątków” miasta: stolica Litwy, cudowny zamek, stojący na górze, oda do Giedyminowego grodu, przyszłość stolicy, stołeczne miasto, podania o zatożeniu miasta, historia Litwy $i$ Wilna, prapoczątki Wilna. Zwraca na siebie uwagę podobieństwo zakresu znaczeniowego podanych peryfraz do definicji Wilna zawartej w słowniku Bogumiła Lindego: ,głowa wszysftkiego Xięftwa Litefkiego, nad rzeką Wiliią i Wilną, od którey i nazwifka ma. Gwag.300 (cf.o wilku żelaznym), Wilna in Lifth. Pry uyściu Wilny rzeki, gdzie do Wilii wpada, Giedymin dwa zamki zbudował, i mianował ie Wilnem od Wilny rzeki, także i miafto prędko się przy zamkach nad Wilną osadziło. Stryik.356, (cf. Rada, Radziwił)"24. Skojarzenia z mitem założycielskim jest typowe dla tradycji litewskiej opisującej Wilno.

\subsection{Wilno jest miastem trzech tradycji i kultur}

Mówiąc o poetyckim obrazie Wilna, Algis Kalèda odwołuje się do poezji polskiej, litewskiej i lacińskiej. Używa przymiotnika wileński w liczbie mnogiej w pozytywnym nacechowaniu emocjonalnym, na przykład literatury wileńskie, jedna z najgłośniejszych fabut wileńskich. Trzech twórców obrazu miasta w literaturze oraz trzy tradycje wileńskie są najważniejsze dla profesora: Czesław 
Milosz (na przykład wyjątkowość dziejowa tej ziemi, magiczne promienie tej ziemi, telluryczne sity tej ziemi), Vaidotas Daunys (na przykład nasze miasto, białe Wilno, nasza rzeka, zamek nasz), Maciej Kazimierz Sarbiewski (na przykład Wilno jak na dłoni, ziemia Palemona, kapitol litewski). Odkrywanie przez Profesora łacińskiego Wilna w wierszach Sarbiewskiego przywodzi na myśl zbieżność z metaforami litewskimi. W pracy Algisa Kaledy nie znajdziemy takich wyrażeń jak: „polskie Wilno” czy „litewskie Wilno”, natomiast Profesor podkreśla wielokulturowość i palimpsestowość wymienionych trzech tradycji: polskiej, litewskiej i łacińskiej. Wręcz zaskakujące jest współistnienie w analizowanym tekście tych tradycji nie tylko w przestrzeni miasta, ale też w czasie, kiedy przeszłość i teraźniejszość tworzy wspólny obraz literackiego Wilna. Wielki palimpsest Wilna (s. 94) jest poetycką metaforą obrazu miasta.

\subsection{Wilno - to centrum wielokulturowości}

Algis Kalèda w swoim zbiorze esejów przywołuje dwie antologie poetyckie - Przenieść Wilno do serca. Portret miasta (2009) oraz Iš Vilniaus i Vilniu. Rinktine poezija (Z Wilna do Wilna. Poezja wybrana, 2008). W pierwszej z nich są przedstawione utwory dotyczące tematyki wileńskiej w twórczości poetów polskich, litewskich, białoruskich (Ihar Babkou), rosyjskich (Georgij Jefremov) i czeskich (Libor Martinek). W drugiej natomiast wiersze XX-wiecznych poetów litewskich, takich jak: Kazys Bradūnas, Henrikas Nagys, Justinas Marcinkevičius, Jonas Strielkūnas, Tomas Venclova, Vladas Braziūnas, Antanas A. Jonynas. Przywołani twórcy konstruują literackie oblicze miasta. W wizji literackiej profesora Algisa Kalėdy nie ma Wilna ani rosyjskiego, ani białoruskiego, ani też żydowskiego czy tatarskiego. Odwołania do tradycji tych narodów występują jedynie w komentarzach Autora do wierszy zawartych w antologii poezji polskiej. Tak na przykład zwraca on uwagę na to, że rzeka Wilenka w wierszu Konstantego Ignacego Gałczyńskiego Noc w Wilnie „łka czarno, ciemno, po rosyjsku”, a „but Nowosilcowa” w utworze Sławomira Worotyńskiego Nad Wilenka - to symbol oprawcy, inicjatora procesu filomatów i filaretów. Z kolei wiersz A. Rybałko To jeszcze Wilno - zdaniem Algisa Kalèdy - z jednej strony sugeruje, że jest to miasto wielowyznaniowe, którego mieszkańcy chodzą między innymi do synagog, ale też przypomina o Holakauście ${ }^{25}$.

25 A. Kalèda, Komentarz, [w:] tegoż, Ieškant poetinès Vilniaus tapatybès, dz.cyt., s. 97. 


\subsection{Wilno - to jego twórcy}

Elementem łączącym ujęcia słownikowe wyrazu „miasto” i Wilna w eseju Algisa Kalėdy jest postać „mieszkańca”. W konotacjach poetyckich obrazu Wilna substytutem „mieszkańca miasta” jest twórca, poeta, pisarz, dlatego ważne jest przyjrzenie się nazwiskom tworzących literackie Wilno. Stereotyp Wilna w rozumieniu Autora eseju jest kluczem do twórczości poetów piszących o tym mieście i reprezentujących różne epoki. Zalicza do ich grona zarówno poetów piszących po łacinie (Macieja Kazimierza Sarbiewskiego), po polsku (Macieja Stryjkowskiego, Andrzeja Rymszę, Jana Kazakowicza Litwina, Eliasza Pielgrzymowskiego, Samuela Dougirda, Daniela Naborowskiego, Stanisława Samuela Szemiota, Jana Czeczota, Karolinę Proniewską), jak też po litewsku (Simonasa Stanevičiusa, Dionizosa Poškę, Tomasa Žičkusa, Maironisa ${ }^{26}$ ).

W swojej pracy W poszukiwaniu poetyckiej tożsamości Wilna Algis Kalėda omawia stan badań nad współczesną poezją polską na Litwie. Przywołuje postaci współczesnych badaczy oraz sylwetki wybitnych polskich twórców związanych z Litwą - wspomina o Adamie Mickiewiczu, Józefie Ignacym Kraszewskim, Władysławie Syrokomli, Czesławie Miłoszu, Konstantym Ildefonsie Gałczyńskim, Witoldzie Hulewiczu, Kazimierze Iłłakowiczównie, Aleksandrze Rymkiewiczu, Teodorze Bujnickim i Zofii Bohdanowiczowej. Po raz kolejny Profesor wyróżnia tradycję łacińską, romantyczną (polską, polskolitewską i litewską) oraz dorobek najważniejszego dla niego twórcy łączącego dwa narody - Czesława Miłosza, którego twórczością zafascynował się jeszcze podczas studiów na Uniwersytecie Jagiellońskim. Poznał zresztą Noblistę osobiście i utrzymywał z nim kontakt korespondencyjny ${ }^{27}$. O ścisłej współpracy i dobrym porozumieniu obu Profesorów świadczy dwujęzyczne, polsko-

26 Tenże, Topika literacka we wspótczesnej poezji polskiej na Litwie, [w:] tegoż, Ieškant poetinès Vilniaus tapatybès, dz.cyt., s. 49-65.

27 W. Zajączkowska, Literackie zwiazki nierozłączne..., dz.cyt.; por. V. Daujotytė, M. Kvietkauskas, Lietuviškieji Česlovo Milošo kontekstai, Vilnius 2011, s. 320. O wyjątkowym stosunku A. Kaledy do twórczości Noblisty świadczy wybór tytułów dwóch ważnych książek - Od M do M. Szkice o literaturze polskiej i litewskiej, Warszawa 2005 oraz Mitu ir poezijos žemé. Lietuva lenku literatūroje. Monografija, Vilnius 2011, a także inne jego publikacje na ten temat. Zob. m.in.: tegoż, Rojaus ieškojimai: metafizinis Miłoszas, [w:] W kręgu idei Miłoszowskich. Studia nad życiem i twórczością Czesława Miłosza, pod red. T. Daleckiej i M. Dawlewicza, Vilnius 2011, s. 17-33. 
litewskie wydanie Poezji wybranych Noblisty (Wilno 1997) ${ }^{28}$. W wywiadzie udzielonym w 2016 roku studentce polonistyki Uniwersytetu Wileńskiego Joannie Rozmysłowicz prof. A. Kalėda wyznał, że najbardziej ceni następujące utwory Czesława Miłosza: poematy Gdzie słońce wschodzi i kędy zapada i Miasto bez imienia, powieść Dolina Issy oraz zbiory esejów Rodzinna Europa, Zniewolony umyst, Szukanie ojczyzny i Druga przestrzeńn ${ }^{29}$. W antologii zamieścił on trzy wiersze pochodzące $\mathrm{z}$ trzech różnych zbiorków poetyckich Noblisty, w tym również z jednego z ostatnich $(T o, 2000)$. Z tego ostatniego zbiorku pochodzi wiersz $W$ mieście, w którym Miłosz wykreował poetycką wizję, czy jak to określił A. Kaleda, „wirtualny obraz” (s. 94), swojego niespełnionego losu, związanego ściśle z miastem studiów i debiutu poetyckiego. Wilno, choć nie nazwane w utworze, zostało określone przez poetę jako „miasto bólu", utracone wraz z losem.

Spośród współczesnych poetów polskich pochodzących z Litwy w omawianej pracy Kalèda przywołuje trzy generacje powojennych autorów, których utwory znalazły się jeszcze w antologii Sponad Wilii cichych fal $^{30}$. Najstarszą generację reprezentują: Jadwiga Bębnowska, Maria Stępowska, Michał Wołosewicz, średnią: Maria Łotocka, Sławomir Worotyński, Wojciech Piotrowicz, oraz podówczas najmłodszą: Aleksander Śnieżko, Henryk Mażul, Romuald Mieczkowski. Do najbardziej produktywnych zalicza: Romualda Mieczkowskiego, Aleksandra Śnieżkę, Aleksandra Sokołowskiego, Alicję Rybałko, a także innych poetów, takich jak: Wojciech Piotrowski, Maria Łotocka, Józef Szostakowski. Niewątpliwie najwyżej ceni twórczość dwojga najbardziej produktywnych poetów z tego grona - Alicji Rybałko i Romualda Mieczkowskiego.

Autor zbioru esejów przeprowadza paralele pomiędzy poezją polską a litewską, przywołując antologie Przenieść Wilno do serca. Portret miasta (Vilnius 2009) i Susitikimai. Spotkania (Vilnius 2013), ponieważ uważa, że „W sposób istotny uzupełniają obraz poetycki Wilna o aspekty komparatystyczne, nadają mu wymiar wielokulturowości". W rozdziale Interpretacje

28 Cz. Miłosz, Rinktiniai eieraščiai/ Poezje wybrane, Vilnius 1997. W przedmowie A. Kalèda napisał: „Serdecznie dziękuję prof. Czesławowi Miłoszowi za udzielone mi konsultacje oraz aprobatę wyboru utworów i projektu niniejszej książki”. W końcu książki znajduje się też posłowie jego autorstwa.

29 J. Rozmysłowicz, Pierwsze spotkanie z Miłoszem było dziwne, dz. cyt.

30 Sponad Wilii cichych fal, wstęp E. Mieżelaitis, Kowno 1985. 
topiki literackiej analizuje przykłady z utworów Sławomira Worotyńskiego, Aleksandra Sokołowskiego, Romualda Mieczkowskiego, Henryka Mażula, Alicji Rybałko oraz przedstawicieli najmłodszego pokolenia poetów - Tomasza Tamošiūnasa i Dariusza Kaplewskiego.

\section{Dialog z literackim obrazem Wilna}

Cykl esejów Algisa Kalėdy o poezji wileńskiej wpisuje się w nurt różnych prac (naukowych, publicystycznych, artystycznych itd.) na temat Wilna i Wileńszczyzny, które zaczęły powstawać w latach 90. XX wieku, kiedy to Litwa rozpoczynała swój byt jako kraj niepodległy ${ }^{31}$. Jeżeli chodzi o polskie środowisko naukowe, to w tej dziedzinie inicjatywa należała do prof. dr hab. Elżbiety Feliksiak (1937-2015), antropolożki, komparatystki i tłumaczki z Uniwersytetu w Białymstoku. Jeszcze w 1989 roku zapoczątkowała ona cykl konferencji pt. Wilno i Wileńszczyzna jako krajobraz i środowisko wielu kultur ${ }^{32}$. Pokłosiem tych konferencji były niezwykle cenne dla badaczy wspomnianej problematyki publikacje wydane przez Białostocki Oddział Towarzystwa Literackiego im. A. Mickiewicza w serii „Biblioteka Pamięci i Myśli””33. Parę lat później, w 1998 roku, podobnej inicjatywy podjęła się również strona litewska. Dzięki literaturoznawczyni dr Almie Lapinskienè z Instytutu Literatury Litewskiej

31 Zob. m.in. artykuły zamieszczone w nr 6 „Odry” z 1990 r.: E. Sawicka, Moje Wilno, dz. cyt. oraz J. Dunin, Wśród wileńskich mitów i realiów, „Odra. Miesięcznik Społeczno-kulturalny" 1990, nr 6, s. 27-30.

32 Kolejne konferencje o tematyce wileńskiej odbyły się w latach: 1994, 1998 i 2000. Do udziału w nich prof. E. Feliksiak zaprosiła przedstawicieli kilku narodowości (Polaków, Litwinów, Rosjan, Białorusinów, Żydów i Tatarów), reprezentujących różne dziedziny humanistyki (literaturoznawstwo, językoznawstwo, historia, historia sztuki, muzykologia, muzealnictwo, bibliotekoznawstwo).

33 Pod red. E. Feliksiak ukazały się m.in. następujące prace zbiorowe: Wilno - Wileńszczyzna jako krajobraz i środowisko wielu kultur. Materiały I Międzynarodowej Konferencji, Biabystok 21-24 IX 1989 w czterech tomach, Białystok 1992; Wilno i Kresy Pólnocno-Wschodnie. Materiały II Międzynarodowej Konferencji, Białystok 14-17 IX 1994 w czterech tomach, Białystok 1996 (współredaktorzy: A. Mironowicz (t. I), A. Kisielewska (t. II), B. Nowowiejski (t. III), A. Kieżuń (t. IV) oraz antologia poetycka Tobie Wilno, Białystok 1992. Godna uwagi jest też jej publikacja: Wileńska pamięć polskiej literatury powojennej. Uwarunkowania i źródła powojennej pamięci, [w:] Kultura międzywojennego Wilna. Materiaty konferencji w Trokach (28-30 IV 1993), pod red. A. Kieżuń, Białystok 1994, s. 9-34. 
i Folkloru w Wilnie w tej placówce odbył się cykl konferencji poświęconych badaniu XX-wiecznego obrazu Wilna jako miasta wieloetnicznego i wielokulturowego ${ }^{34}$. Przedmiot badań naukowców polskich i litewskich był ten sam, różniły się natomiast ramy chronologiczne badanych zjawisk. Cykl publikacji wydanych przez Instytut Literatury Litewskiej i Folkloru dotyczył wyłącznie Wilna z lat 1900-1945, czyli z okresu, kiedy mogło ono pełnić funkcję stolicy Litwy tylko symbolicznie, ale takiej roli w opinii Litwinów nigdy nie utraciło. Autorzy tekstów zamieszczonych w materiałach konferencji białostockich byli zaliczani do tzw. wileńskiej wspólnoty (określenie Elżbiety Feliksiak), łączył je rodowód wileński, często też doświadczenie wojny, repatriacji, zsyłek i skazanie na życie w oddaleniu od małej ojczyzny. Natomiast tylko niektórzy uczestnicy konferencji wileńskich są urodzeni w Wilnie, dla większości z nich (przede wszystkim Litwinów) jest to „ojczyzna przybrana”, w której ich przodkowie znaleźli się po II wojnie światowej.

Prof. Algis Kaleda był przez dłuższy czas jedynym litewskim historykiem literatury, który popularyzował problematykę dotyczącą literatury polskiej w ramach cyklu wspomnianych konferencji wileńskich. Rzecz znamienna, że jedna z pierwszych jego publikacji (w języku litewskim) na ten temat dotyczyła toposu ojczyzny w twórczości wileńskiej grupy literackiej „Żagary” (1931-1934) 35 . Już w tej pracy z 1998 roku wskazał on na główny kierunek swoich badań z zakresu literatury polskiej - analizę lokalnej poezji w szerokim kontekście, zaczynając od utworów twórców należących do tzw. wileńskiej szkoły romantycznej i kończąc na wierszach poetów współczesnych, urodzonych w przełomie lat 50. i 60. (Romuald Mieczkowski, Alicja Rybałko). Analizę tę śmiało można nazwać pierwszą próbą określenia poetyckiej tożsamości Wilna, w której na tamtym eta-

34 A. Lapinskienė dokonała wyboru i opracowania prac, które znalazły się m.in. w następujących tomach: Vilniaus kultūrinis gyvenimas 1900-1940, Vilnius 1998; Vilniaus kultūrinis gyvenimas ir Petras Viliešis, Vilnius 2001; Vilniaus kultūrinis gyvenimas. Moteru indèlis 1900-1945, Vilnius 2005; Vilniaus kultūrinis gyvenimas. Tautu polilogas 1900-1945, Vilnius 2012. Cechą wyróżniającą konferencje organizowane przez A. Lapinskienè oraz przygotowane przez nią do druku materiały jest to, że referaty są wygłaszane i drukowane w kilku językach: litewskim, polskim, rosyjskim i białoruskim. Publikacje te są też wzbogacone o cenne zdjęcia archiwalne.

35 A. Kalèda, Tèvynès vaizdiniai „Žagaru“ " grupès kūryboje, [w:] Vilniaus kultūrinis gyvenimas 1900-1940, sudarytoja A. Lapinskienè, Vilnius 1998, s. 248-255. Por. A. Zieniewicz, Idace Wilno. Szkice o Żagarach, Warszawa 1987; S. Bereś, Ostatnia wileńska plejada. Szkice o poezji kregu Żagarów, Warszawa 1990. 
pie drogi naukowej prof. Kalèdy najwięcej miejsca zajmowała poezja Żagarystów. Jego badania w tej dziedzinie były pokrewne badaniom podjętym przez prof. dra hab. Tadeusza Bujnickiego z UJ, który w tamtym okresie pełnił funkcję swego rodzaju łącznika pomiędzy Białymstokiem a Wilnem (jako jedyny brał udział w obu cyklach konferencji). Praca prof. Bujnickiego Obraz Wilna w międzywojennej poezji wileńskiej jest najbardziej wyczerpującym opracowaniem na ten temat, prof. Kalèda cytuje ją zarówno we wspomnianym tekście o toposie ojczyzny w twórczości Żagarystów ${ }^{36}$, jak też - obok wypowiedzi Czesława Miłosza - w analizowanym eseju Oblicza miasta ${ }^{37}$.

Innym kontekstem dla omawianej pracy Kalèdy może też być tekst Tomasza Śmigielskiego, który przedstawia 13 mitycznych obrazów Wilna w dwudziestoleciu międzywojennym ${ }^{38}$. „Poetycka historia” miasta wykreowana przez Kalèdę różni się zarówno od powyższej oraz innych, proponowanych przez niektórych badaczy polskich, na przykład prof. Stanisława Lorentza ${ }^{39}$. W wizji Wilna tego historyka sztuki i muzealnika można wyróżnić takie elementy krajobrazu miasta, jak: położenie wśród wzgórz i pagórków, przy ujściu Wilenki do Wilii; widok z lotu ptaka oraz architektura miejska typowa dla różnych epok (gotyku, renesansu, baroku, rokoka, klasycyzmu). Natomiast w poetyckim obrazie Wilna u Kalèdy dominuje ujęcie symboliczno-metaforyczne, choć odmienne od tego, jakie proponuje Tomasz Śmigielski. Brakuje w nim odwołań do innych niż poezja Żagarystów zjawisk z życia kulturalnego Wilna w okresie dwudziestolecia międzywojennego, co jest typowe na przykład dla prac Marcelego Kosmana, Elżbiety Feliksiak czy Tadeusza Bujnickiego. Profesor polonistyki wileńskiej

36 T. Bujnicki, Obraz Wilna w międzywojennej poezji wileńskiej (1922-1939), [w:] Wilno - Wileńszczyzna jako krajobraz i środowisko wielu kultur. Materiały I Międzynarodowej Konferencji, Białystok 21-24 IX 1989 - w czterech tomach, pod red. E. Feliksiak, t. IV, Białystok 1992, s. 321-350. Por. A. Kalèda, Tèvynès vaizdiniai „Žagaru“" grupés kūryboje, dz. cyt., s. 250.

37 A. Kalèda, Oblicza miasta, [w:] tegoż, Ieškant poetinès Vilniaus tapatybès, dz. cyt., s. 19.

38 Wymienia on m.in. takie obrazy Wilna, jak: warownia, kościót, Jeruzalem Niebieska, Wieczne Miasto Rzym, feniks, Florencja Północy, Ateny Litewskie, Litewska Szwajcaria, Litwinka, Arka. Zob. T. Śmigielski, Mityczne obrazy Wilna w literaturze okresu międzywojennego, [w:] Wilno i Kresy Pólnocno-Wschodnie. Materiaty II Międzynarodowej Konferencji w Biatymstoku 14-17 IX 1994 w czterech tomach, t. IV Literatura, pod red. E. Feliksiak i A. Kieżuń, Białystok 1996, s. 177-202.

39 S. Lorentz, Moje wizje Wilna, [w:] Wilno-Wileńszczyzna ..., t. I Krajobraz i ludzie, dz. cyt., s. 13-26. 
uwzględnia natomiast dorobek wielu pokoleń wilnian, który ma wymiar sakralny, mityczny i metafizyczny. Jego zdaniem , poezja wileńska” jest „,swego rodzaju palimpsestem powstałym z doświadczenia wielu pokoleń” (s. 24).

Inny obszar badawczy Kalėdy, współczesna poezja Polaków na Litwie, jest - jego zdaniem - obszarem wciąż jeszcze mało rozpoznanym (choć badanym od prawie $30 \mathrm{lat}^{40}$ ), ale stosunkowo bogatym. Dotychczas ukazało się ponad 50 tomików poetyckich (antologii i zbiorków autorskich) twórców z Wilna i Litwy, które stały się obiektem badań studentów polonistyki i doczekały się fachowych opracowań i analiz ${ }^{41}$. Cechami charakterystycznymi tej twórczości są: jej znaczne zróżnicowanie gatunkowe i stylistyczne (od stylizowanej „twórczości ludowej” po poezję społecznie zaangażowaną i wreszcie - „synkretyczną twórczość nowoczesną"), silna więź z kulturą Wielkiego Księstwa Litewskiego, tradycją romantyczną oraz wykorzystanie współczesnych toposów-tematów miasta (zapożyczonej między innymi od Miłosza). Cechy te są jeszcze jednym dowodem na palimpsestowość poezji wileńskiej, zresztą nie tylko polskojęzycznej, ale też - jak dowodzi Kalėda - również najnowszej litewskiej.

\section{Zakończenie}

Reasumując, można stwierdzić, że obraz miasta powstaje w eseju dzięki przywołaniom nazwisk twórców, utworów i nazw ze sfery urbanistyczno-architektonicznej. Są to na przykład elementy krajobrazu zawarte w wierszach poetów wielojęzycznych: Góra Giedymina, Ostra Brama, Zarzecze, Cmentarz na Rossie, Ulica Zamkowa itd. ${ }^{42}$ Wilno jako przestrzeń architektoniczno-urba-

40 Badania nad współczesną poezją polską Wileńszczyzny zostały podjęte po ukazaniu się antologii Sponad Wilii cichych fal, dz.cyt. Problematykę badali m.in. T. Bujnicki, J. Podgórski, K. Woźniakowski.

41 Najwięcej opracowań na ten temat opublikowała doc. dr H. Turkiewicz z Litewskiego Uniwersytetu Edukologicznego. Zob. tejże: Wilno w twórczości wspótczesnych polskich poetów Litwy, [w:] Wilno i kresy pótnocno-wschodnie, dz. cyt., s. 287-306; Wielokulturowe reminiscencje w poezji regionalistów wileńskich, [w:] Tożsamość na styku kultur, t. II, Zbiór studiów, pod red. I. Masojć i H. Sokołowskiej, Wilno 2011, s. 295-308; H. Turkiewicz, Wspótczesna polska poezja Wileńszczyzny. Kontekst litewski, [w:] Tożsamość na styku kultur, t. III, Zbiór studiów, pod red. I. Masojć i H. Sokołowskiej, Wilno 2016, s. 118-132.

42 A. Kalèda, Topika literacka we współczesnej poezji polskiej na Litwie, [w:] tegoż, Ieškant poetinès Vilniaus tapatybès, dz.cyt., s. 49-65. 
nistyczna omówiona jest na postawie wierszy Czesława Miłosza, Sławomira Worotyńskiego, Alicji Rybałko, Romualda Mieczkowskiego i innych.

Konotacje semantyczne Wilna w analizowanej pracy Algisa Kalėdy mają charakter wyłącznie afirmacyjny. Wilno jest często określane wyrazem „miasto” (dostrzegamy tu podobieństwo do poezji Czesława Miłosza) i postrzegane jako palimpsest trzech tradycji (polskiej, litewskiej i łacińskiej), jako miejsce wyjątkowe, o niepowtarzalnym genius loci. Językowy obraz Wilna wykreowany w zbiorze esejów Kalèdy jest w tym opisie jeszcze niepełny, należałoby go wzbogacić o dane językowe i literackie występujące w innych tekstach Profesora.

Jaka jest relacja pomiędzy literacką wizją miasta a rzeczywistością pozaliteracką? Autor eseju podkreśla, że miasto daje siłę, jest miejscem magicznym. Na pewno Profesor bardzo je kochał nie tylko w literaturze, ale też jako rzeczywistość, gdyż tu studiował i później, po powrocie na Litwę, mieszkał przez 40 lat. Zbadany odcinek twórczości eseistycznej Algisa Kalėdy w przyszłości można uzupełnić o paralelne teksty w języku litewskim, wszystkie jego tłumaczenia na język litewski oraz Jego własną twórczość poetycką.

\section{Bibliografia podmiotowa}

Kalèda A. , leškant poetinés Vilniaus tapatybés / W poszukiwaniu poetyckiej tożsamości Wilna/ In search of poetical identity of Vilnius, Wilno 2016, s. 16-24, 49-65.

\section{Bibliografia przedmiotowa}

Bartmiński J. , Perspektywa semazjologiczna i onomazjologiczna badaniach językowego obrazu świata, „Poradnik Językowy” 2015, z. 1, s. 14-29.

Bartmiński J. , S. Niebrzegowska, Profile a podmiotowa interpretacja świata, [w:] Profilowanie w języku i w tekście, pod red. J. Bartmińskiego, R. Tokarskiego, Lublin 1998, s. 211-224.

Bereś S. , Ostatnia wileńska plejada. Szkice o poezji kręgu Żagarów, Warszawa 1990.

Bujnicki T. , Obraz Wilna w międzywojennej poezji wileńskiej (1922-1939), [w:] Wilno - Wileńszczyzna jako krajobraz i środowisko wielu kultur. Materiały I Między- 
narodowej Konferencji, Białystok 21-24 IX 1989 - w czterech tomach, pod red. E. Feliksiak, t. IV, Białystok 1992, s. 321-350.

Bujnicki T. , Uwagi o badaniach nad literaturą (na dziesięciolecie Katedry Filologii Polskiej), [w:] tegoż, Na pograniczach, kresach i poza granicami. Studia, oprac. tekstu i red. tomu M. Siedlecki i Ł. Zabielski, Białystok 2014.

Daujotytè V. , M. Kvietkauskas, Lietuviškieji Česlovo Milošo kontekstai, Vilnius 2011. Dabartinés lietuvių kalbos žodynas, pod red. S. Keinysa, Vilnius 2012, wersja elektroniczna 2015 http://lkiis.lki.lt/, hasło miestas (dostęp: 12.12. 2017).

Dunin J. , Wśród wileńskich mitów i realiów, „Odra. Miesięcznik Społeczno-kulturalny" 1990, nr 6, s. 27-30.

Fedorowicz I. , „Filologia kłopotliwej mniejszości”. Wczoraj i dzisiaj polonistyki na Uniwersytecie Wileńskim, „Rocznik Stowarzyszenia Naukowców Polaków Litwy” 2016, t. 16, s. 103-117.

Feliksiak E. , Wileńska pamięć polskiej literatury powojennej. Uwarunkowania i źródła powojennej pamięci, [w:] Kultura międzywojennego Wilna. Materiały konferencji w Trokach (28-30 IV 1993), pod red. A. Kieżuń, Białystok 1994, s. 9-34.

Grzegorczykowa R. , Pojęcie językowego obraz świata, [w:] Językowy obraz świata, pod red. J. Bartmińskiego, Lublin 1990, s. 39-46.

Kadyjewska A. , Problematyka obrazu świata w badaniach języka pisarza (na przykładzie pism Cypriana Norwida), [w:] Semantyka tekstu artystycznego, pod red. A. Pajdzińskiej, R. Tokarskiego, Lublin 2001, s. 321-332.

Kalèda A. , Mitu ir poezijos žemé. Lietuva lenku literatūroje. Monografija, Vilnius 2011. Kalèda A. , Od M do M. Szkice o literaturze polskiej i litewskiej, Warszawa 2005.

Kalèda A. , Pomiędzy dwiema Ojczyznami, „Kwartalnik Polonicum” 2015, nr 18, s. 44-49.

Kalèda A. , Rojaus ieškojimai: metafizinis Miłoszas, [w:] W kręgu idei Miłoszowskich. Studia nad życiem i twórczością Czesława Miłosza, pod red. T. Daleckiej i M. Dawlewicza, Vilnius 2011, s. 17-33.

Kalèda A. , Sugestywność poezji Teodora Bujnickiego (z perspektywy odbiorcy litewskiego), [w:] Teodor Bujnicki - ostatni bard Wielkiego Księstwa Litewskiego, red. naukowa i wstęp T. Bujnicki, Białystok 2012, s. 153-164.

Kalèda A. , Szukanie Wilna, czyli jak być Europejczykiem, [w:] W ogrodzie świata. Profesorowi Aleksandrowi Fiutowi na siedemdziesiąte urodziny, pod red. Ł. Tischnera i J. Wróbla, Kraków 2015, s. 221-230. 
Kalèda A. , Tèvynès vaizdiniai "Žagaru“ grupès kūryboje, [w:] Vilniaus kultūrinis gyvenimas 1900-1940, sudarytoja A. Lapinskienè, Vilnius 1998, s. 248-255.

Kozłowska A. , Problemy z idiolektem, [w:] Język pisarzy jako problem lingwistyki, pod red. T. Korpysza, A. Kozłowskiej, t. II, Warszawa 2009, s. 111-131.

Kultura międzywojennego Wilna. Materiały konferencji w Trokach (28-30 IV 1993), pod red. A. Kieżuń, Białystok 1994.

SJPD - Słownik języka polskiego, pod red. W. Doroszewskiego, t. I-XI, Warszawa 1958-1969 (wersja elektroniczna: https://sjp.pwn.pl/doroszewski/miastol;5451010.html).

SL - S.B. Linde, Słownik języka polskiego, t. I-IV, Warszawa 1807-1814, wersja elektroniczna: http://kpbc.umk.pl/dlibra/publication?id=8173 (dostęp: 12.12. 2017).

Lorenz S. , Moje wizje Wilna, [w:] Wilno - Wileńszczyzna jako krajobraz i środowisko wielu kultur. Materiały I Międzynarodowej Konferencji, Białystok 21-24 IX 1989 - w czterech tomach, pod red. E. Feliksiak, t. I Krajobraz i ludzie, Białystok 1992, s. $13-26$.

Miłosz Cz. , Rinktiniai eièraščiai/ Poezje wybrane, Vilnius 1997.

Niebrzegowska-Bartmińska S. , O profilowaniu językowego obrazu świata, „Poradnik Językowy" 2015, nr 1, s. 30-44.

Rozmysłowicz J. , Pierwsze spotkanie z Miłoszem było dziwne. Wywiad z prof. A. Kalèdą: zw.It/radar-wilenski/kaleda-pierwsze-spotkanie-z-miloszem-bylo-dziwne (dostęp: 17.05. 2016).

Sawicka E., Moje Wilno, „Odra. Miesięcznik Społeczno-kulturalny” 1990, nr 6, s. 21-26. Sponad Wilii cichych fal, wstęp E. Mieżelaitisa, Kowno 1985.

Śmigielski T. , Mityczne obrazy Wilna w literaturze okresu międzywojennego, [w:] Wilno i Kresy Północno-Wschodnie. Materiały II Międzynarodowej Konferencji w Białymstoku 14-17 IX 1994 w czterech tomach, t. IV Literatura, pod red. E. Feliksiak i A. Kieżuń, Białystok 1996, s. 177-202.

Tobie Wilno. Antologia poetycka, wybór i red. E. Feliksiak, M. Skorko i P. Waszaka, wyd. 2 rozsz., Białystok 1992.

Tokarski R. , Słownictwo jako interpretacja świata, [w:] Encyklopedia kultury polskiej XX wieku, t. II. Współczesny język polski, pod red. J. Bartmińskiego, Wrocław 1993.

Turkiewicz H. , Wielokulturowe reminiscencje w poezji regionalistów wileńskich, [w:] Tożsamość na styku kultur, t. II, Zbiór studiów, pod red. I. Masojć i H. Sokołowskiej, Wilno 2011, s. 295-308. 
Turkiewicz H. , Wilno w twórczości współczesnych polskich poetów Litwy, [w:] Wilno i Kresy Północno-Wschodnie. Materiały II Międzynarodowej Konferencji w Białymstoku 14-17 IX 1994 w czterech tomach, t. IV Literatura, pod red. E. Feliksiak i A. Kieżuń, Białystok 1996, s. 287-306.

Turkiewicz H. , Współczesna polska poezja Wileńszczyzny. Kontekst litewski, [w:] Tożsamość na styku kultur, t. III. Zbiór studiów, pod red. I. Masojć i H. Sokołowskiej, Wilno 2016, s. 118-132.

Vilniaus kultūrinis gyvenimas 1900-1940, sudarytoja A. Lapinskienè, Vilnius 1998. Vilniaus kultūrinis gyvenimas ir Petras Vilešis, sudarytoja A. Lapinskienè, Vilnius 2001.

Vilniaus kultūrinis gyvenimas. Moteru indèlis 1900-1945, sudarytoja A. Lapinskienè, Vilnius 2005.

Vilniaus kultūrinis gyvenimas. Tautu polilogas 1900-1945, sudarytoja A. Lapinskienè, Vilnius 2012.

Zajączkowska W. , Literackie związki nierozłączne. Rozmowa z doc. dr. Algisem Kalèdą, kierownikiem Katedry Filologii Polskiej Uniwersytetu Wileńskiego, „Słowo Wileńskie" 1996, nr 20 (17-23 maja), s. 9.

Zieniewicz A. , Idące Wilno. Szkice o Żagarach, Warszawa 1987. 